\title{
Colombian Creole horse breeds: Same origin but different diversity
}

\author{
Ligia Mercedes Jimenez ${ }^{1}$, Susy Mendez ${ }^{2}$, Susana Dunner ${ }^{2}$, Javier Cañón ${ }^{2}$ and Óscar Cortés ${ }^{2}$ \\ ${ }^{1}$ Department of Animal Production Science, Facultad de Medicina Veterinaria y Zootecnia, \\ Universidad Nacional de Colombia, Bogotá, Colombia. \\ ${ }^{2}$ Department of Animal Production, Facultad de Veterinaria, Universidad Complutense, Madrid, Spain.
}

\begin{abstract}
In order to understand the genetic ancestry and mitochondrial DNA (mtDNA) diversity of current Colombian horse breeds we sequenced a 364-bp fragment of the mitocondrial DNA D-loop in 116 animals belonging to five Spanish horse breeds and the Colombian Paso Fino and Colombian Creole cattle horse breeds. Among Colombian horse breeds, haplogroup D had the highest frequency (53\%), followed by haplogroups $A(19 \%), C(8 \%)$ and $F(6 \%)$. The higher frequency of haplogroup $D$ in Colombian horse breeds supports the theory of an ancestral Iberian origin for these breeds. These results also indicate that different selective pressures among the Colombian breeds could explain the relatively higher genetic diversity found in the Colombian Creole cattle horse when compared with the Colombian Paso Fino.
\end{abstract}

Key words: Colombian, Creole cattle horse, horse breeds, mitochondrial DNA, Paso Fino horse breed.

Received: January 13, 2012; Accepted: July 5, 2012.

\section{Introduction}

Native horses of the Iberian Peninsula have played an important role in the development of current American horse breeds. Approximately 10,000 years ago, North and South American Equus species became extinct for several reasons (Grooves and Ryder, 2000). Horses returned to the Americas during the second trip of Christopher Columbus to the Island of Hispaniola in 1493 (present-day Dominican Republic and Haiti) (Laguna-Sanz, 1991; Rodero et al., 1992; Fedequinas, 2006). Initially, colonizing the New World territories was not considered a worthwhile experience. Consequently, the first horses brought to America by Columbus were not carefully selected, as revealed by complaints from Christopher Columbus to the Catholic kings about the quality of these animals (Cabrera, 1945; Sponenberg, 1992). It is likely that the original horses were replaced before their departure to America by peasant stock breeds called "jacas" located in Sevilla (Rodero et al., 1992; Sponenberg, 1992). In the years following the expeditions by Columbus, conquering the New World became more important and the quality of the horses brought to America improved. As a result, horse breeds brought to America during this period varied in quality and origin, al-

Send correspondence to Ligia Mercedes Jiménez Robayo. Department of Animal Production Science, Facultad de Medicina Veterinaria y Zootecnia, Universidad Nacional de Colombia, Sede Bogotá, C/Carrera 30 № 45-03, Bogotá DC, Colombia. E-mail: Imjimenezr@unal.edu.co. though most came from the southern Iberian Peninsula (Cabrera, 1945; Rodero et al., 1992; Sponenberg, 1992).

Traditionally, Iberian horses have been classified into two groups: Celtic ponies, in reference to breeds distributed throughout the North Atlantic Iberian region, and Iberian horses located throughout the southern Iberian Peninsula (Aparicio, 1944; Jordana et al., 1995; Villar, 1996; Jordana and Pares, 1999). Several studies have postulated that Iberian Celtic ponies share a common ancestry with British ponies, whereas Iberian horses share a common ancestry with the Barb horse (Garcia-Dory, 1980; Sotillo and Serrano, 1985; Álvarez Llana, 1995; Martinez et al., 1996a,b; Jansen et al., 2002). The high degree of genetic diversity among Iberian horse breeds suggests that the Iberian Peninsula served as a refugium for wild horses and has contributed considerably to local domestic stock, as well as to the domestic horse breeds of central Europe and the United Kingdom (Warmuth et al., 2011).

Horses from the Iberian Peninsula entered Colombia through two main routes. One route was established by the expeditions of Alonso de Ojeda and Diego de Nicuesia in 1509 (Diaz, 1988) and went through Panama via the Gulf of Uraba to Nueva Granada (= New Granada; present-day Colombia). The second route was established by Spanish expeditions through Coro (present-day Venezuela) to the Eastern Plains region known as "Llanos Orientales" in Nueva Granada, in the current departments of Arauca, Casanare and Meta (Montoya B, 1988, undergraduate final work, Universidad de Los Llanos, Villavicencio, Colombia). 
The horses that arrived via the first route are known today as the Colombian Paso Fino horse breed and are found throughout most of Colombia. The marshy areas from which the Paso Fino breed came favored the development of a typical gait very suitable for agriculture or riding. Through years of selection, the Colombian Paso Fino breed has been aptly divided into four lineages based on their natural gait: the Colombian Paso Fino, Colombian Trocha, Colombian Trocha-Gallop and Colombian Trot-Gallop (Fedequinas, 2006).

Horses that arrived in Colombia via the second route gave rise to the Colombian Creole cattle horse breed (known as Criollo de Vaquería). This breed occurs in three geographic regions, including the departments of Arauca, Casanare and Meta, which make up part of the "Llanos Orientales" near the Colombian-Venezuelan border. Traditionally, these horses have been used in agriculture and have been kept isolated in a state of semi-freedom in herds formed by mares, colts and stallions, without much selective pressure (Sandoval RFA and Torres MTI, 1996, undergraduate final work, Universidad de Los Llanos, Villavicencio, Colombia).

The mitochondrial DNA control region has been widely used to understand the origin and diversification of domestic horses (Vilá et al., 2001; Mirol et al., 2002; Luis et al., 2006; Kavar and Dov, 2008; Warmuth et al., 2011). Previous studies have discovered high levels of mitochondrial DNA variability within and among horse breeds, without a clear geographical pattern of distribution (Hill et al., 2002). Recent studies have confirmed the Iberian Peninsula as a geographic maternal and genetic refugium, a conclusion supported by the finding that several pre-domestic Iberian maternal lineages survive in modern horses of Iberian descent (Warmuth et al., 2011). Specifically, haplogroup D1, as defined by Jansen et al. (2002), is well represented in both southern Iberian and New World breeds, thus highlighting the importance of Iberian breeds during re-population of the New World by horses (Royo et al., 2005; Luis et al., 2006). Despite the clear connection between horses found in the Iberian Peninsula and horses found in the Americas today, the influence of the Iberian horse gene pool on Colombian Creole horses has not yet been analyzed.

The aim of this study was to analyze the two principal horse populations in Colombia, the Colombian Paso Fino and the Colombian Creole cattle horse, in order to clarify their maternal genetic origin and the current matrilineages in both breeds.

\section{Materials and Methods}

In total, 116 blood samples were collected from unrelated animals representing the Colombian Paso Fino (CPF), the Colombian Creole cattle horse (from the Casanare (CVC) and Meta (CVM) populations) and the following five Iberian horse breeds: Asturcon (AST), Caballo Gal- lego (CGA), Jaca Navarra (JNA), Losino (LOS) and Pura Raza Española (PRE) (Table 1). Figure 1 shows the geographic distribution of each sample.

DNA was extracted using a Qiagen DNeasy Blood \& Tissue kit (Qiagen, Germany) according to the manufacturer's instructions. A 364-bp fragment of the mtDNA D-loop that included positions 15469-15832 (Xu and Arnason, 1994) was sequenced. The primer sequences were designed using the Primer 0.5 software (GCG Software Package, University of Wisconsin, USA). The primers used were D-LOOPF (5'-CCACCATCAACACCCAAAGC-3') and D-LOOPR (5'-GCCCTGAAGAAAGAACCAGAT3 '). The amplified fragments were purified using a Purelink PCR purification kit (Invitrogen), according to the manufacturer's instructions. Sequencing was done using an ABI PRISM 310 Genetic Analyzer (Applied Biosystems) and the sequences were aligned using ClustalX (Thompson et al., 1997). The mean number of pairwise differences (MNPD), nucleotide diversity and $\mathrm{F}_{\mathrm{ST}}$ distances were obtained using MEGA 4.1 (Tamura et al., 2007) and ARLEQUIN 3.11 (Excoffier et al., 2005) softwares. Partitioning of the total genetic variance into components based on intergroup (Colombian and Spanish), interbreed and inter-individual differences was done using analysis of molecular variance (AMOVA) implemented in ARLEQUIN 3.11 (Excoffier et al., 2005). Median-joining networks were generated using NETWORK 4.5.1.0 (Bandelt et al., 1995).

\section{Results}

The sequencing of mtDNA from the 116 blood samples of Colombian and Spanish horse breeds revealed 51 haplotypes defined by 69 polymorphisms ( 52 transitions and 17 transversions) distributed among 63 distinct sites.

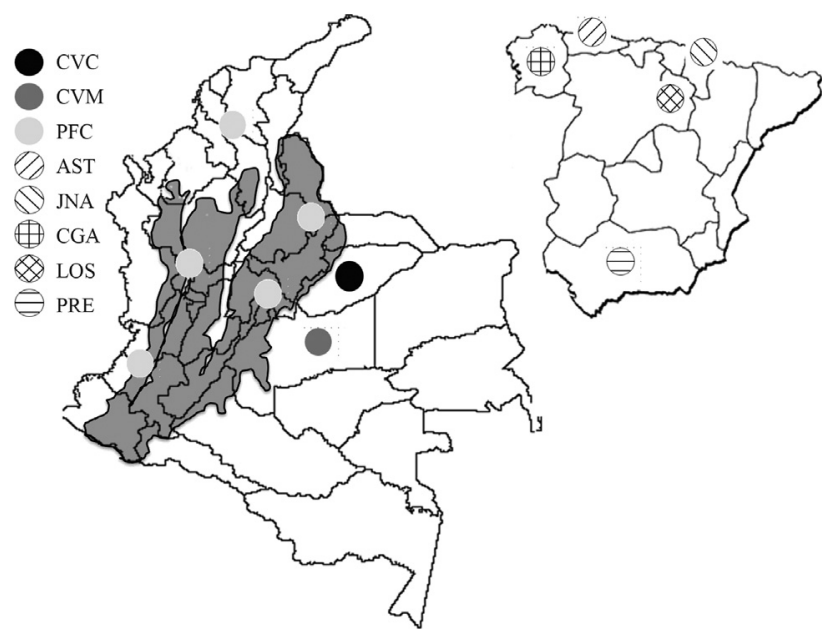

Figure 1 - Geographic location of the Colombian (the shaded areas correspond to the three Colombian mountain chains) and Spanish horse breed samples. AST - Asturcon, CGA - Caballo Gallego, CVC - Colombian Creole cattle horse from Casanare, CVM - Colombian Creole cattle horse from Meta, JNA - Jaca Navarra, LOS - Losino, PFC - Colombian Paso Fino and PRE - Pura Raza Española. 
Table 1 - Haplotypes and haplogroups in a 364-bp fragment of the mitochondrial DNA D-loop of Colombian and Spanish horse breeds. Site nomenclature is based on the classification of Jansen et al. (2002). AST - Asturcon, CGA - Caballo Gallego, CVC - Colombian Creole cattle horse from Casanare, CVM - Colombian Creole cattle horse from Meta, JNA - Jaca Navarra, LOS - Losino, PFC - Colombian Paso Fino and PRE - Pura Raza Española.

\begin{tabular}{|c|c|c|c|c|c|c|c|c|c|}
\hline \multirow[t]{3}{*}{ Identification } & \multicolumn{8}{|c|}{ Haplotypes } & \multirow[t]{3}{*}{ Haplogroups } \\
\hline & \multicolumn{3}{|c|}{ Colombian breeds } & \multicolumn{5}{|c|}{ Spanish breeds } & \\
\hline & $\mathrm{CVC}$ & CVM & $\mathrm{PFC}$ & AST & JNA & CGA & LOS & PRE & \\
\hline Hap_01 & 3 & 0 & 0 & 0 & 0 & 0 & 0 & 0 & A1 \\
\hline Hap_02 & 9 & 5 & 5 & 1 & 0 & 1 & 3 & 4 & D1 \\
\hline Hap_03 & 2 & 2 & 3 & 2 & 0 & 1 & 1 & 0 & D1 \\
\hline Hap_04 & 1 & 0 & 0 & 0 & 0 & 0 & 0 & 0 & $\mathrm{C} 1$ \\
\hline Hap_05 & 2 & 0 & 0 & 0 & 0 & 0 & 0 & 0 & D1 \\
\hline Hap_06 & 1 & 0 & 0 & 0 & 0 & 0 & 0 & 0 & New (D) \\
\hline Hap_07 & 1 & 0 & 0 & 0 & 0 & 0 & 0 & 0 & New (D) \\
\hline Hap_08 & 4 & 0 & 1 & 0 & 0 & 0 & 0 & 1 & $\mathrm{~A} 3$ \\
\hline Hap_09 & 1 & 0 & 1 & 0 & 0 & 0 & 0 & 0 & D1 \\
\hline Hap_10 & 1 & 0 & 0 & 0 & 0 & 0 & 0 & 0 & D1 \\
\hline Hap_11 & 1 & 0 & 0 & 0 & 0 & 0 & 0 & 0 & New (F) \\
\hline Hap_12 & 1 & 0 & 0 & 0 & 0 & 0 & 0 & 0 & A3 \\
\hline Hap_13 & 1 & 0 & 0 & 0 & 0 & 0 & 1 & 0 & A3 \\
\hline Hap_14 & 1 & 0 & 0 & 0 & 0 & 0 & 0 & 0 & $\mathrm{C} 2$ \\
\hline Hap_15 & 1 & 2 & 0 & 0 & 0 & 1 & 0 & 0 & $\mathrm{C} 2$ \\
\hline Hap_16 & 0 & 2 & 0 & 0 & 0 & 1 & 0 & 0 & New (A) \\
\hline Hap_17 & 0 & 1 & 0 & 0 & 0 & 0 & 0 & 0 & A1 \\
\hline Hap_18 & 0 & 1 & 0 & 0 & 0 & 0 & 0 & 0 & New (A) \\
\hline Hap_19 & 0 & 1 & 0 & 0 & 0 & 0 & 0 & 0 & New (F) \\
\hline Hap_20 & 0 & 1 & 0 & 0 & 0 & 0 & 0 & 0 & D1 \\
\hline Hap_21 & 0 & 1 & 0 & 1 & 4 & 0 & 0 & 0 & D3 \\
\hline Hap_22 & 0 & 1 & 0 & 0 & 0 & 0 & 0 & 0 & New (A) \\
\hline Hap_23 & 0 & 1 & 0 & 0 & 0 & 0 & 0 & 0 & New (A) \\
\hline Hap_24 & 0 & 1 & 0 & 0 & 0 & 0 & 0 & 0 & D1 \\
\hline Hap_25 & 0 & 0 & 1 & 0 & 0 & 0 & 0 & 0 & D1 \\
\hline Hap_26 & 0 & 0 & 1 & 0 & 0 & 0 & 0 & 0 & $\mathrm{C} 2$ \\
\hline Hap_27 & 0 & 0 & 1 & 0 & 0 & 0 & 0 & 0 & D1 \\
\hline Hap_28 & 0 & 0 & 1 & 0 & 0 & 0 & 0 & 0 & D1 \\
\hline Hap_29 & 0 & 0 & 1 & 0 & 0 & 0 & 0 & 0 & $\mathrm{C} 2$ \\
\hline Hap_30 & 0 & 0 & 0 & 1 & 0 & 0 & 0 & 0 & D1 \\
\hline Hap_31 & 0 & 0 & 0 & 1 & 0 & 0 & 0 & 0 & D1 \\
\hline Hap_32 & 0 & 0 & 0 & 1 & 0 & 0 & 0 & 0 & D1 \\
\hline Hap_33 & 0 & 0 & 0 & 1 & 0 & 0 & 0 & 0 & New (A) \\
\hline Hap_34 & 0 & 0 & 0 & 1 & 0 & 0 & 0 & 0 & D1 \\
\hline Hap_35 & 0 & 0 & 0 & 1 & 0 & 0 & 0 & 0 & $\mathrm{~F} 2$ \\
\hline Hap_36 & 0 & 0 & 0 & 1 & 0 & 0 & 0 & 0 & $\mathrm{C} 2$ \\
\hline Hap_37 & 0 & 0 & 0 & 0 & 3 & 0 & 0 & 0 & A5* \\
\hline Hap_38 & 0 & 0 & 0 & 0 & 1 & 0 & 0 & 0 & New (A) \\
\hline Hap_39 & 0 & 0 & 0 & 0 & 1 & 0 & 0 & 0 & A6 \\
\hline Hap_40 & 0 & 0 & 0 & 0 & 1 & 1 & 0 & 1 & D3 \\
\hline Hap_41 & 0 & 0 & 0 & 0 & 1 & 0 & 0 & 0 & New $(C-F)^{\dagger}$ \\
\hline Hap_42 & 0 & 0 & 0 & 0 & 0 & 1 & 0 & 1 & F2 \\
\hline Hap_43 & 0 & 0 & 0 & 0 & 0 & 1 & 0 & 0 & A1 \\
\hline Hap_44 & 0 & 0 & 0 & 0 & 0 & 1 & 0 & 0 & D2 \\
\hline Hap_45 & 0 & 0 & 0 & 0 & 0 & 1 & 0 & 0 & D1 \\
\hline Hap_46 & 0 & 0 & 0 & 0 & 0 & 0 & 2 & 0 & $\mathrm{C} 2$ \\
\hline Hap_47 & 0 & 0 & 0 & 0 & 0 & 0 & 2 & 0 & New (C) \\
\hline Hap_48 & 0 & 0 & 0 & 0 & 0 & 0 & 1 & 0 & $\mathrm{~A} 3$ \\
\hline Hap_49 & 0 & 0 & 0 & 0 & 0 & 0 & 0 & 1 & A3 \\
\hline Hap_50 & 0 & 0 & 0 & 0 & 0 & 0 & 0 & 1 & New (D) \\
\hline Hap_51 & 0 & 0 & 0 & 0 & 0 & 0 & 0 & 1 & A1 \\
\hline Total $(\mathrm{N})$ & 30 & 19 & 15 & 10 & 11 & 11 & 10 & 10 & \\
\hline
\end{tabular}

*Reference sequence X79547 (Xu and Arnason, 1994). "Haplotype 41 shared 50\% similarity with haplogroups C and F. 
Five sites contained transitions and transversions and one site had two unique transversions (Figure S1).

For each breed, we identified between six and 15 haplotypes. The Colombian Creole cattle horse from Casanare (CVC) (15) and Asturcon (AST) (10) showed the highest number of haplotypes among the Colombian Creole horse populations and Spanish breeds, respectively (Table 1). The CVC and AST populations also had a higher frequency of haplotypes exclusive of the other breeds studied ( $60 \%$ and $70 \%$, respectively). Seven haplotypes were common to Spanish and Colombian horse breeds (haplotypes $2,3,8,13,15,16$ and 21 ). Only 10 haplotypes were found in more than one breed and 41 haplotypes were unique to a single breed (Table 1). The CVC (9) and Jaca Navarra (JNA) (7) populations had a higher number of exclusive haplotypes among Colombian and Spanish breeds, respectively. Haplotypes $2(24 \%)$ and $3(10 \%)$ had a total frequency of $34 \%$, whereas the frequencies of all other individual haplotypes varied from $0.9 \%$ to $5 \%$ of the total haplotypes (Table 1).

Thirty-eight haplotypes coincided with Jansen's haplogroup classification (Jansen et al., 2002) and were assigned to nine previously defined haplogroups (A1, A3, A5, A6, C1, C2, D1, D3 and F1) (Table 1); the remaining 13 haplotypes were classified as new haplotypes (Table 1). The most frequently identified haplotypes in the Colombian and Spanish breeds were type D1 (47\%), A3 (10\%) and C2 (9\%). Haplotype D1 was considered to be representative of Iberian and North African breeds and was found in every breed analyzed except Jaca Navarra (Table 2).

Figure 2 shows the network analysis for the 51 haplotypes. The skeleton network revealed four main clusters that corresponded to the four haplogroups (A, C, D, and F)

Table 2 - Haplogroup frequencies (in percentage) in Colombian and Iberian horse breeds. AST - Asturcon, CGA - Caballo Gallego, CVC - Colombian Creole cattle horse from Casanare, CVM - Colombian Creole cattle horse from Meta, JNA - Jaca Navarra, LOS - Losino, PFC - Colombian Paso Fino and PRE - Pura Raza Española.

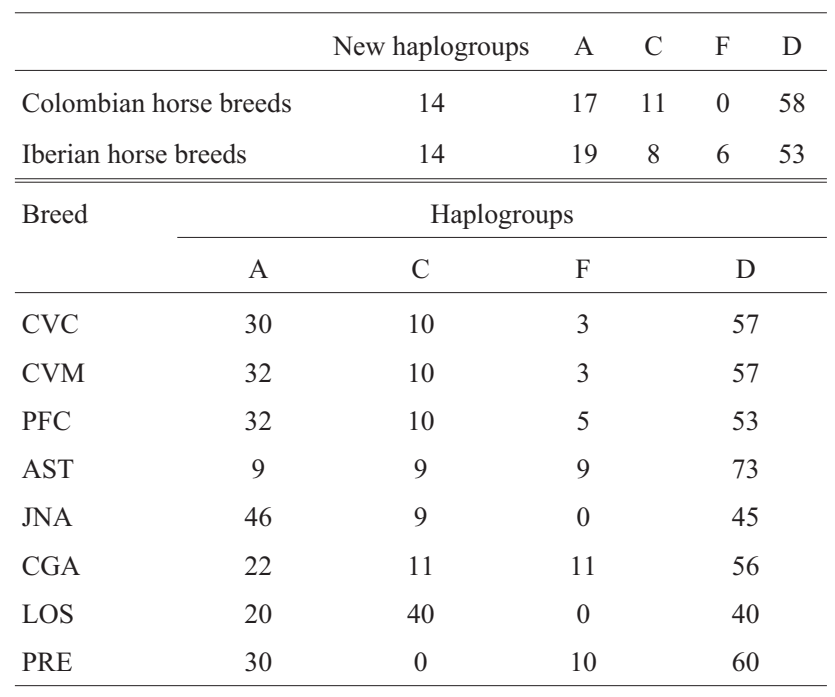

described by the classification system of Jansen et al. (2002). The haplotypes belonging to haplogroup D showed a star-like skeleton in which the center of the star corresponded to the haplotype with the highest frequency (2) surrounded by a number of peripheral haplotypes of lower frequency. The 13 new haplotypes were distributed among the four haplogroups. Most of the different horse breeds were represented in all four haplogroups, the exceptions being Pura Raza Española, which was absent in haplogroup $\mathrm{C}$, and Losino and Jaca Navarra, which were absent in haplogroup F.

The haplotype diversity, nucleotide diversity and mean number of pairwise differences were similar for the Colombian and Iberian breeds (Table 3). However, the Colombian Paso Fino breed had lower nucleotide diversity than the other Colombian and Spanish breeds. Haplotype diversity ranged from 0.97 in Pura Raza Española to 1 in the Gallego breed. Among Colombian breeds, the Colombian Creole cattle horse from Meta had the highest value (0.92) whereas the Colombian Paso Fino breed had the lowest nucleotide diversity $(0.0114)$ and the lowest mean number of pairwise differences (4.2)

The average $\mathrm{F}_{\mathrm{ST}}$ distance between any two breeds ranged from just under 3\% to $12 \%$ (Table 3 ). The Colombian Creole horse populations had values at the lower end of this range $(2.7-4.9 \%)$ whereas the Spanish breeds had higher values ranging from $6.2 \%$ to $11.5 \%$.

AMOVA of the various haplotypes revealed no significant genetic differences among the Spanish and Colombian breeds $\left(\mathrm{F}_{\mathrm{CT}}=1 \%\right)($ Table 4$)$. However, this lack of genetic differentiation between groups was not reflected in the differences among breeds within groups or among breeds between different groups $\left(\mathrm{F}_{\mathrm{ST}}=5 \%\right.$ and $\left.\mathrm{F}_{\mathrm{SC}}=5 \%\right)$.

\section{Discussion}

Several studies have confirmed the importance of Iberian horses in the repopulation of the New World with Equus species (Mirol et al., 2002; Luis et al., 2006). However, this is the first genetic analysis of the two principal Colombian equine breeds (Colombian Creole Cattle horse or Criollo de Vaquería and Colombian Paso Fino). Our results show that several haplogroups are shared by Iberian and Colombian horse breeds. Haplotypes of haplogroup D were found more often than any other haplotype in the Colombian and Iberian horse breeds analyzed. Haplogroup D is representative of the ancestral horse populations of the Iberian Peninsula, thus supporting historical records of Iberian ancestry in the development of Colombian horse breeds (Miretti et al., 2004; Primo, 2004; Luis et al., 2006).

Haplogroup A has previously been found in the Marismeño breed, which is an ancient semi-feral population that occurs in Doñana Natural Park in Spain (Royo et al., 2005). We have identified haplotype $\mathrm{A}$ in some of the Colombian horse breeds analyzed, including the Sevillan 
Jacas breed, which is closely related to the extant Marismeño horse breed, thus explaining the origin of haplogroup A in Colombian horse breeds (Rodero et al., 1992; Spo- nenberg, 1992). This finding confirms historical documents that report the presence of the Sevillan Jacas breed among the horses brought to America.

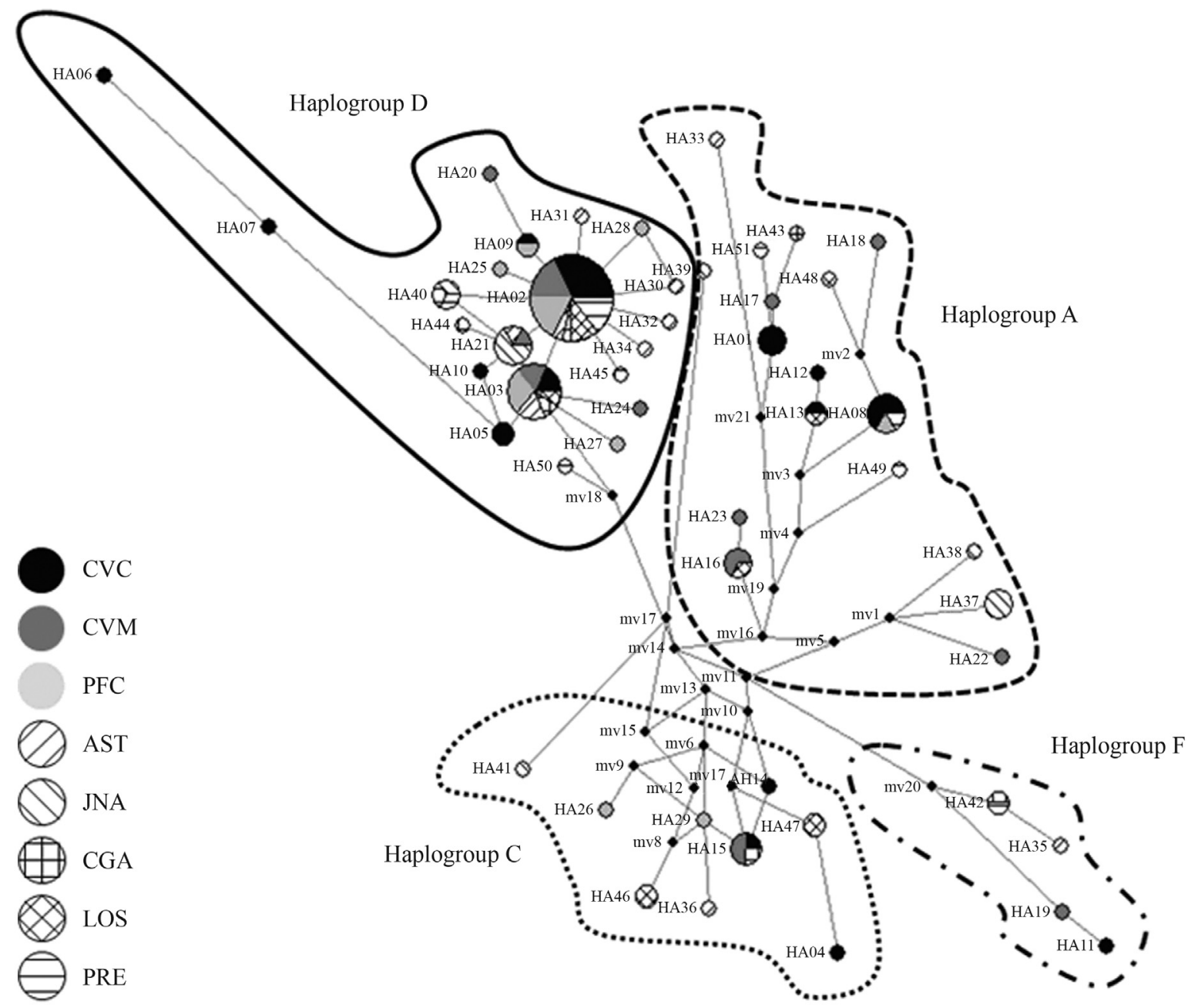

Figure 2 - Network representation of the 51 haplotypes identified in Colombian and Spanish horse breeds. The size of the circles is proportional to their frequencies. Oval shapes indicate the haplogroup classification based on Jansen et al. (2002). AST - Asturcon, CGA - Caballo Gallego, CVC - Colombian Creole cattle horse from Casanare, CVM - Colombian Creole cattle horse from Meta, JNA - Jaca Navarra, LOS - Losino, PFC - Colombian Paso Fino and PRE - Pura Raza Española.

Table 3 - Haplotype diversity, nucleotide diversity, mean number of pairwise differences in the Colombian and Iberian breeds and average $\mathrm{F}_{\mathrm{ST}}$ distance between each breed relative to the others. AST - Asturcon, CGA - Caballo Gallego, CVC - Colombian Creole cattle horse from Casanare, CVM - Colombian Creole cattle horse from Meta, JNA - Jaca Navarra, LOS - Losino, PFC - Colombian Paso Fino and PRE - Pura Raza Española.

\begin{tabular}{|c|c|c|c|c|c|c|c|c|}
\hline & \multicolumn{3}{|c|}{ Colombian breeds } & \multicolumn{5}{|c|}{ Iberian Breeds } \\
\hline & $\mathrm{CVC}$ & CVM & PFC & AST & JNA & CGA & LOS & PRE \\
\hline Haplotype diversity & 0.89 & 0.92 & 0.876 & 0.981 & 0.836 & 1 & 0.888 & 0.866 \\
\hline Mean & & 0.99 & & & & 0.98 & & \\
\hline Nucleotide diversity & 0.023 & 0.021 & 0.011 & 0.021 & 0.022 & 0.022 & 0.022 & 0.022 \\
\hline Mean & & 0.024 & & & & 0.024 & & \\
\hline Mean number of pairwise differences & 8.2 & 7.6 & 4.2 & 7.5 & 7.9 & 7.9 & 7.9 & 7.9 \\
\hline Mean & & 8.8 & & & & 8.7 & & \\
\hline Average $\mathrm{F}_{\mathrm{ST}}$ distance & 4.9 & 3.8 & 2.7 & 9.0 & 11.5 & 6.8 & 9.5 & 6.2 \\
\hline
\end{tabular}


Table 4 - Partitioning of the genetic variability among the different sources of variation.

\begin{tabular}{lcc}
\hline Source of variation & Variation (\%) & Fixation indices \\
\hline Among groups (Colombian breeds $v s$. Iberian breeds) & 0.57 & $\mathrm{~F}_{\mathrm{CT}}: 0.00574$ \\
Among breeds within groups & 5.41 & $\mathrm{~F}_{\mathrm{SC}}: 0.05446$ \\
Among individuals within breeds & 94.01 & $\mathrm{~F}_{\mathrm{ST}}: 0.05989$ \\
\hline
\end{tabular}

Haplogroup C is representative of Celtic horses. The identification of haplogroup $\mathrm{C}$ in the Colombian horse breeds studied here most likely reflects the authorization to import Celtic horses to Nueva Granada, which included present-day Panama and Colombia (Luis et al., 2006). Haplogroup F was not identified in the Colombian horse breeds, but the closely-related haplotypes 11 and 19 were found in the Colombian Creole cattle horse (Criollo de Vaquería) breed. Haplogroup F, which is found in Middle Eastern breeds, could be related to the Berber phenotype found in Colombian breeds. Further research in this area should shed light on the corresponding haplotype-phenotype relationships.

The proportion of the total variance explained by the genetic differences among Iberian and Colombian horse breeds was low ( $1 \%$ and data not shown) as a consequence of the Iberian origin of the Colombian breeds. Nevertheless, the variance explained by the differences between breeds was higher (6\%) because of reproductive isolation after the colonization event and because of genetic drift.

The reduced diversity of New World horse breeds when compared with Iberian breeds is consistent with an Iberian origin. Previous studies that included South American horse breeds support this theory (Luis et al., 2006). As expected, the Colombian Paso Fino breed had a lower degree of genetic diversity than Iberian breeds. In contrast, the Colombian Creole cattle horse breed showed a similar degree of genetic diversity to that of the Iberian breeds analyzed. The Colombian Paso Fino breed is considered to have undergone selective breeding because of its characteristic gait, which renders it very suitable for riding. Conversely, the Colombian Creole cattle horse breed has been kept in relative isolation with very little selective pressure. The different selection processes applied to Colombian breeds could explain the high genetic diversity found in the Colombian Creole cattle horse relative to the Colombian Paso Fino horse.

Our network analysis of the mtDNA D-loop sequences discovered 51 haplotypes that could be classified into four main clusters that formed the four principal haplogroups (A, C, D and F). The 13 new haplotypes identified in our sequences were distributed among the four clusters. The heterogeneity of the Marismeño breed, in which haplogroup A has previously been identified, could explain the high number of unidentified haplotypes (six of 13) that aligned within this haplogroup.

In conclusion, four principal matrilineages have been found in the two principal Colombian horse breeds. Haplo- group $\mathrm{D}$, which is representative of the ancestral Iberian horse population, was discovered most often in Colombian breeds, thus supporting the ancestral Iberian origin of Colombian horses. The higher degree of genetic diversity found in the Colombian Creole cattle horse when compared with either the Colombian Paso Fino or other South American horse breeds is a consequence of significantly different selective pressures in both populations.

\section{Acknowledgments}

We thank Drs. Bernardo Vasquez Herrera and Beatriz Salgado Garcia of the Federación Nacional Colombiana de Asociaciones Equinas de Colombia (FEDEQUINAS) for providing the Paso Fino horse samples, Dr. Francisco Sandoval for providing the Colombian Creole cattle horse samples, and A.C.P.R.A. for providing the Asturcon samples. We also thank R. Parellada, E. Martin, M.I. Panadero and Eva Solano for technical assistance during this work.

\section{References}

Álvarez Llana J (1995) Morfología y Caracteres Raciales. Editorial Asturcones Caja de Asturias, Oviedo, 93 pp.

Aparicio SG (1944) Zootecnia Especial. 4th edition. Editorial S.E.V., Córdoba, 364 pp.

Bandelt H-J, Forster P, Sykes BC and Richards MB (1995) Mitochondrial portraits of human populations. Genetics 141:743-753.

Cabrera A (1945) Caballos de América. Editorial Sudamericana, Buenos Aires, 405 pp.

Díaz GE (1988) 50 Años Tras las Huellas de Nuestro Caballo de Paso Fino Colombiano. Editorial Impresores Colombianos, Bogotá, 252 pp.

Excoffier L, Laval G and Schneider S (2005) Arlequin ver. 3.0: An integrated software package for population genetics data analysis. Evol Bioinform Online 1:47-50.

Fedequinas (2006) El Caballo Colombiano. Cinco Siglos de Historia. Imprelibros, Bogotá, 403 pp.

García-Dory MA (1980) Asturcón: Caballo de los Astures. Ediciones Caja de Ahorros de Asturias, Oviedo, 84 pp.

Grooves GP and Ryder OA (2000) Systematics and phylogeny of the horse. In: Bowling AU and Ruvinsky A (eds) The Genetics of the Horse. CABI Publishing, New York, pp 1-24.

Hill EW, Bradley DG, Al-Barody M, Ertigrul O, Splan RK, Zakharov I and Cunningham EP (2002) History and integrity of thoroughbred dam lines revealed in equine mtDNA variation. Anim Genet 33:287-294.

Jansen T, Forster P, Levine MA, Oelke H, Hurles M, Renfrew C, Weber J and Olek K (2002) Mitochondrial DNA and the origins of the domestic horse. Proc Natl Acad Sci USA 99:10905-10910. 
Jordana J and Parés PM (1999) Relaciones genéticas entre razas ibéricas de caballos utilizando caracteres morfológicos (prototipos raciales). AGR 26:75-94.

Jordana VJ, Parés PM and Sánchez A (1995) Analysis of genetic relationships in horse breeds. J Equine Vet Sci 15:320-328.

Kavar T and Dove P (2008) Domestication of the horse: Genetic relationships between domestic and wild horses. Livest Sci 116:1-14.

Laguna-Sanz E (1991) El Ganado Español un Experimento para América. Ministerio de Agricultura, Madrid, 237 pp.

Luis C, Bastos-Silveira C, Gus Cortan E and Oom MM (2006) Iberian origins of New World horse breeds. J Hered 97:107113.

Martínez SJM, Valera CM and Molina AA (1996a) Caballo Gallego de monte (Poney Gallego). AGR 19:45-56.

Martínez SJM, Valera CM and Molina AA (1996b) El caballo Losino. AGR 19:17-26.

Miretti MM, Dunner S, Naves M, Contel EP and Ferro JA (2004) Predominant African-derived mtDNA in Caribbean and Brazilian Creole cattle is also found in Spanish cattle (Bos taurus). J Hered 95:450-453.

Mirol PM, Peral García P, Vega-Pla JL and Dulout FN (2002) Phylogenetics relationships of Argentinean Creole horses and other South American and Spanish breeds inferred from mitochondrial DNA sequences. Anim Genet 33:356-363.

Primo AT (2004) América: Conquista e Colonização: A Fantástica História dos Conquistadores Ibéricos e Seus Animais na Era dos Descobrimentos. Editora Movimento, Porto Alegre, $184 \mathrm{pp}$.

Rodero A, Delgado JV and Rodero E (1992) Primitive Andalusian livestock and their implications in the discovery of America. Arch Zootec 41:383-400.

Royo LJ, Álvarez A, Beja-Pereira A, Molina A, Fernández I, Jordana J, Gómez E, Gutiérrez JP and Goyache F (2005) The origins of Iberian horses assessed via mitochondrial DNA. J Hered 96:663-669.
Sotillo JL and Serrano V (1985) Producción Animal. I. Etnología Zootécnica. Editorial Tebar-Flores, Madrid, 405 pp.

Sponenberg DP (1992) The colonial Spanish horse in the USA: History and current status. Arch Zootec 41:335-348.

Tamura K, Dudley J, Nei M and Kumar S (2007) MEGA4: Molecular Evolutionary Genetics Analysis (MEGA) software ver. 4.0. Mol Biol Evol 24:1596-1599.

Thompson JD, Gibson TJ, Plewniak F, Jeanmougin F and Higgins DG (1997) The ClustalX windows interface: Flexible strategies for multiple sequence alignment aided by quality analysis tools. Nucleic Acids Res 24:4876-4882.

Vilá C, Leonard JA, Gotherstrom A, Marklund A, Sandberg K, Liden K, Wayne RK and Ellegreen H (2001) Widespread origins of domestic horse lineages. Science 291:474-477.

Villar F (1996) Los Indoeuropeos y los Orígenes de Europa: Lenguaje e Historia. Editorial Gredos, Madrid, 614 pp.

Warmuth V, Eriksson A, Bower MA, Cañon J, Cothran G, Distl O, Glowatzki-Mullis ML, Hunt $\mathrm{H}$, Luis C, Oom $\mathrm{M}$ et al. (2011) European domestic horses originated in two Holocene refugia. PloS One 6:18194.

Xu X and Arnason U (1994) The complete mitochondrial DNA sequence of the horse, Equus caballus: Extensive heteroplasmy of the control region. Gene 148:357-362.

\section{Supplementary Material}

The following online material is available for this article:

Figure S1 - Variable sites in a 364-bp fragment of the mitochondrial DNA D-loop of Colombian and Spanish horse breeds.

This material is available as part of the online article from http://www.scielo.br/gmb.

Associate Editor: Bertram Brenig

License information: This is an open-access article distributed under the terms of the Creative Commons Attribution License, which permits unrestricted use, distribution, and reproduction in any medium, provided the original work is properly cited. 
VARIABLE SITES AND NUCLEOTIDIC POSITION

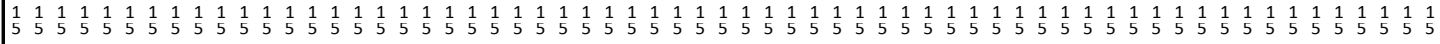

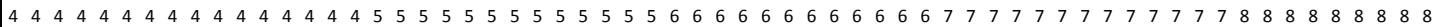

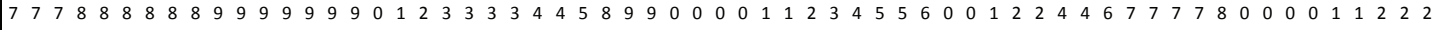

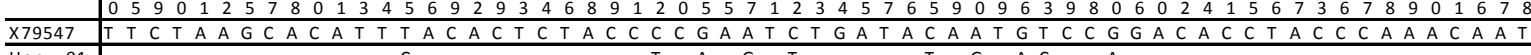

Hap_-01

Hap_-_02

Hap_-_03

Hap_-05

Hap_-_06

Hap_-07

Hap_-08
Hap_09

Hap__10

Hap_-11

Hap--12

Hap_-13

Hap__14

Hap_- 16

Hap__17

Hap_- 18

Hap_20

Hap_-_21

Hap 22

Hap_-_23

Hap_-_24

Hap 26

Hap__27

Hap_-28

Hap__29

Hap_-30

Hap_-31

Hap

Hap 34 T A T

Hap_-35 35

Hap_-36

Hap_-37

Hap_-38

Hap_-39
Hap_40

Hap_-41

Hap_-_42

Hap_-43

Hap_-44

Hap_-45

Hap__46

Hap_-_47

Hap_-48

Hap_-49

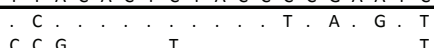

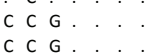

$\begin{array}{ll}C & C G \\ C & G T\end{array}$

. C G T
. C G.

. C

C CG. .

C C G

T. . . . T.

\begin{tabular}{lllllllll}
$T$ & $C$ &. &. &. &. &. & $G$ & G \\
T & $C$ &. &. &. &. &. & $G$ \\
\hline
\end{tabular}

$\mathrm{T}$

T C. . . G

$T \cdot T \cdot A \cdot A$

. $T$

G. T $T$

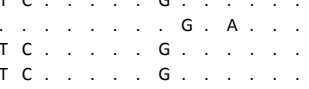

C. G G .

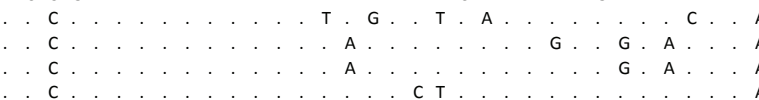

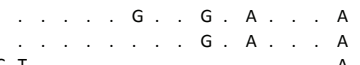

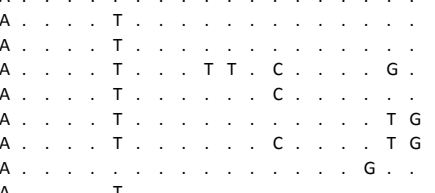

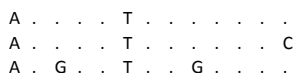

G T G G G G G G G

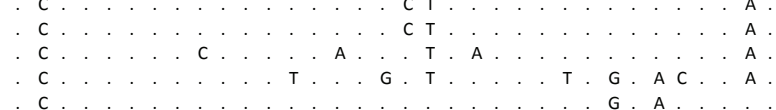

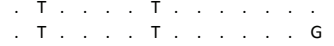

A

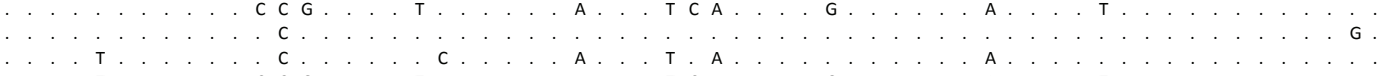

. . . . . C

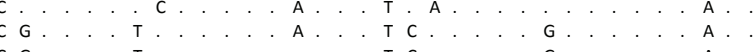

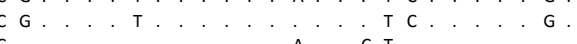

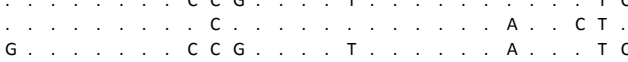

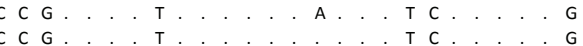

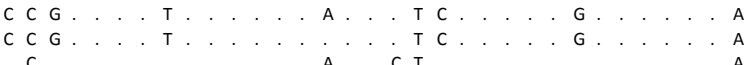

C $C G$. C T . . . . . . A . A .

. . . . . . . . A A

C C G C.. T T..

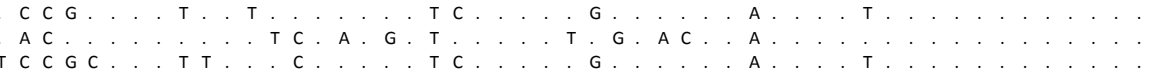

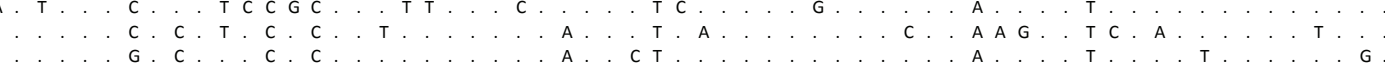

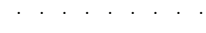

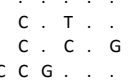

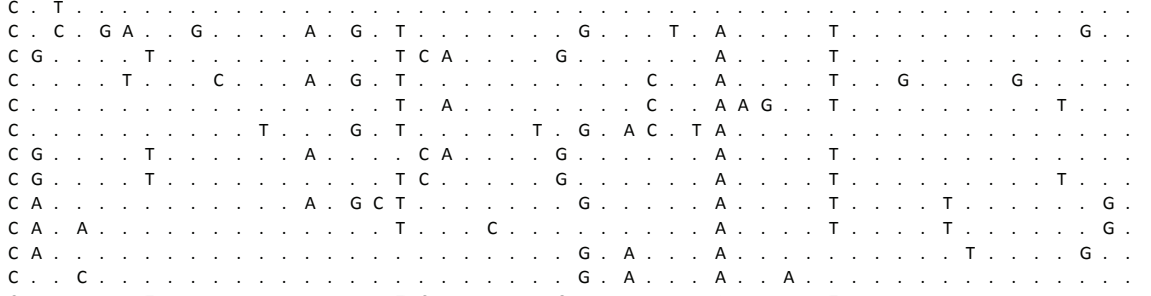

